\title{
Harmonization Among Religion, Culture, and Nature in Selametan Khitanan Tradition in Demak
}

\author{
Vina Uctuvia ${ }^{1 *}$, Deli Nirmala ${ }^{2}$ \\ ${ }^{1}$ Department of Linguistics, Faculty of Humanities, Diponegoro University, Semarang - Indonesia \\ ${ }^{2}$ Department of Linguistics, Faculty of Humanities, Diponegoro University, Semarang - Indonesia
}

\begin{abstract}
Selametan khitanan tradition in Demak is accomplished when a son is going to puberty marked by the act of circumcision, which is called sunatan. The objective of this paper is to examine what are the communication patterns in selametan khitanan tradition in Demak. The data is restricted to khitan prayer and traditional songs accompanying barongan performance so that the discussion of the study can be specific. This descriptive qualitative study employs the ethnographic concept of communication with unit analysis theory by Saville-Troike and the communication pattern concept by Dell Hymes. There are three sub communication events, namely tahlilan and khataman, arak-arakan, and barongan performance. As seen from a series of processions in which religiosity are seen in the khitan prayers, cultural elements are seen in the barongan performance, and natural elements that appear during the barongan performance are accompanied by traditional songs that contain meanings related to nature in the lyrics. In the selametan khitanan, there is a harmonious relationship between religion, culture, and nature found by exploring the meaning of khitan prayer and traditional songs lyrics.
\end{abstract}

\section{Introduction}

Javanese society is very well known as a society that cannot be separated from tradition and culture. Traditional ceremonies, which are examples of tradition and culture, are joint ceremonies that still have racial, ethnic and cultural links. Almost all certain ceremonies of Javanese society have unique rituals so that the rituals in Java have many variations. Geographical, historical, and social backgrounds dominate the diversity of traditions and cultures in Java. In the postmodern era, Javanese society still has high acculturation of Islamic values. The existence of Javanese culture that developed in the regions shows that Islam spread in Indonesia through cultural elements. We can see them in the areas around Pantura such as Jepara, Demak, Pati, Kudus, and Rembang. The cultural traditions of the Javanese people in these areas are still very prominent with Javanese or traditional culture and customs.

In the expression of gratitude, because their son is going to puberty which is marked by the act of cutting or removing part or all of the foreskin of the penis, which is called sunat, the Javanese people living in Demak perform a selametan khitanan with several sessions

* Corresponding author: vinauctuvia@gmail.com 
after the sunat itself. The boys who are circumcised are referred to by the local community as pengantin sunat because of the boy's particular costume, similar to a bride with full makeup and accessories. This submissive procession is usually carried out within a certain period after sunat is carried out, depending on the readiness of the boys' parents who have been sunat. There are several series of selametan khitanan settlement which is divided into three parts. The first series of processions is the recitation of tahlil by the family and residents and the implementation of khataman juz 'amma by the pengantin sunat. After the procession of tahlilan and khataman, a procession is carried out around the village. Then it is closed with a barongan attraction specially performed in selametan khitanan.

The focus of the research is on the communication patterns of the procession of selametan khitanan tradition in Demak, intending to describe how the communication patterns of the procession of selametan khitanan pengantin sunat in Demak and revealing the significance in the procession of selametan khitanan as a manifestation of a religious and cultural form of Demak societies. The data used by the researchers are limited to khitan prayer, and some traditional songs related to barongan performance in the procession of selametan khitanan in Demak can be elaborated so that the research discussion can be centred and focused. In the data, harmony between culture and religion in the khitan prayer and some traditional songs that are used to accompany the barongan performance, which is one of the series of processions during the selametan khitananan in Demak. According to Sasaki et al. [1], Religion assists people in maintaining a sense of control, especially secondary control (acceptance and adjustment to challenging situations), and it leads to the development of social relationships within a religious group.

Some researchers have conducted studies on circumcision (sunat) tradition and the relationship between religion and culture. For example, Ananda et al. [2] discussed the circumcision tradition of the tribal girl of Makassar, especially in the community of Manggar Baru, Balikpapan East district, Balikpapan city. The research examined and established the steps of Makassar native female circumcision in Balikpapan, in order to ascertain the importance found in the Makassar tribal female circumcision practice in Balikpapan. The study showed that the process of carrying out the makatte (circumcision) ritual is carried out by a sanro anaq. Sanro anaq is the name for someone who has been trusted to do the makatte ritual. In this makatte ritual, there are five stages that must be done ; (i) Mandi bersih, (ii) Dikalawing, (iii) Rippabbajui, (iv) Pa'barazanji, (v) Makkatte, and (vi) Cerak. In every stage of the Makkatte ritual, there is a unique meaning and goal contained in it. The researchers also found three values in the tradition of Makassar tribal female circumcision in Balikpapan: religious, ethical, and aesthetic values.

Another study that examined circumcision was conducted by Erwanto, [3] in his research which has focused on the Muayak tradition at the Banding Agung Oku (South Sumatra) community circumcision ceremony, found that the local culture was created by the Ranau community with the power of creativity required to produce inner experiences. It is even used as an experience of the life of the ranau community, which is essentially part of the art that tries to display actual and imaginative values of beauty related to reflections on various kinds of problems related to humans. This research examines the cultural and moral values of the muayak tradition at the Banding Agung OKU community circumcision ceremony. Based on the research results of the traditional muayak at the Banding Agung community circumcision ceremony, it can be concluded that there are cultural and moral values in this muayak. Cultural values include cultural values in human relations with God, cultural values in human interactions with other people, cultural values in human interactions with culture, cultural values in human interactions with the environment, and cultural values in human interactions with self. Furthermore, universal values are divided into three categories: spiritual-moral values, personal moral values, and social, moral values. 
Ahmad [4] conducted similar research entitled Sekaten Tradition: The Ritual Ceremony in Yogyakarta as Acculturation Reality of Javanese Culture in Indonesia. His study used communication ethnography to discuss the acculturation reflected in the ceremonial communication of the sekaten ceremony. The results of his research revealed that the ceremonial artifact conveys a strong nonverbal meaning through the use of cultural acculturation symbols. The symbols also have a relation to philosophy in everyday life. Symbols used in the sekaten ceremony include: (i) Gamelan sekaten sets, (ii) Numpak wajik, (iii) Distributing udhik-udhik, and (iv) Gunungan sekaten. There are several signs with fascinating meanings. The signs are unquestionably communication media that reflect the philosophy, Javanese culture, and Islamic influence. The Sekaten ceremony depicts not only ceremonial activities but also elements of art, social, history, and education; they are; (i) Economic aspects, (ii) Social and cultural aspects, (iii) Political aspects, and (iv) Religion aspects. As a traditional communication media, sekaten ceremony has a function to preserve Javanese culture. The function of communication in sekaten ritual ceremony is among others as follows: (i) As information media, (ii) As entertainment activity, and (iii) As bridge between king and people.

From several related studies, researchers are interested in examining more deeply the groom circumcision procession in Demak, which focuses on the communication patterns that exist in it. The approach to be used is the Ethnographic approach which will then be analyzed and described after obtaining the data from the instruments used.

\section{Research Method}

This This research is descriptive qualitative research. Sources of the research data were secondary data. The data were obtained from observations of the selametan khitanan procession via YouTube video (https://www.youtube.com/watch? $\mathrm{v}=\mathrm{oPV}$ 6G_PPBc). The researchers used non-participatory observation methods. Nonparticipation observation is a relatively unobtrusive qualitative research technique for collecting primary data regarding any aspect of the social environment without having to communicate with the participants directly [5]. Related to the data, the researchers used a note-taking technique.

Demak is an area geographically located in Central Java, which was the basis for the spread of Islam by Walisongo. Sunan Kalijaga was one of the nine wali who made the culture and traditions of the local community as a medium of preaching so that Islam, which was new to the Javanese at that time, could easily be accepted. Islamic preaching taught by the Walisongo in creating harmony in a polite and tolerant manner. So that many Javanese people embrace Islam because the preaching style of the guardians is inclusive. Javanese society needs a transition period from the Hindu tradition to a new tradition, namely Islam Nusantara. On the one hand, they believe and acknowledge the truth that is drawn from the teachings of Islam, but on the other hand, they still believe in things related to the pre-Islamic cultural heritage tradition, namely Hinduism-Buddhism.

Observation and interviews are to gather the data. The researchers used the observation method to observe the selametan khitanan tradition in Demak, while the interview method was used to obtain more accurate details about the procession selametan khitanan in Demak from several informants who took part in and carried out the procession. Michael declares data from observations include detailed descriptions of people's activities, behaviours, and actions, as well as the whole range of interpersonal relations and organizational practices that can be observed as part of the human experience [6]. According to Sandy, one of the essential qualitative data collection methods, the research interview, has been popularly used in field research and ethnographic research [7]. The data was then analyzed using domain analysis techniques based on the unit of analysis theory proposed by Dell Hymes in Saville-Troike [8]. In ethnography of communication, the unit analysis concerns settings, events, and acts 
to explain and interpret the behaviours and patterns of communication [9]. Intertextual analysis was used to analyze the harmonization among religion, culture, and nature in the procession of selametan khitanan in Demak. Intertextuality links can be viewed as either implicit or explicit connections [10].

\section{Result and Discussion}

The procession of selametan khitanan in Demak is the object of this study, which focuses on communication patterns in khitan prayer and traditional song during the procession of selametan khitanan in Demak. The data were analyzed using the principle of Dell Hymes in Saville-Troike [8], specifically the setting (communication situation), event (communication event), and act (communication act). The communication pattern theory (proposed by Saville-Troike also used to analyze the data.

\subsection{Communication Setting}

There are several series of the procession of the selametan khitanan; the first is the procession of reading the tahlil and the khataman procession, followed by the procession of the bride and groom circumcision, and closed with a barongan performance. Participants in the tahlil and khataman processions are all villagers and relatives of the circumcision bride who come dressed modestly. Male participants usually wear a sarong, and a koko dress equipped with a cap and are given a place to sit together at the front of the house. Female participants come wearing polite clothes in Islam called covering their genitals and are provided with a place to sit together with the inside of the house so that male and female participants do not mingle. What is unique and looks different from the others is the circumcised bride who in the khataman procession uses clothes that are specially designed to resemble a prince who is equipped with all the accessories. In the khataman procession, the is given a special place with a boat-shaped podium that has been decorated in such away. Of the three processions, the setting takes place in the house of the circumcised bride, the village streets, the houses of the village elders and the bride's closest relatives, and the house's yard. For all the procession of the selametan khitanan, circumcision is carried out from morning to noon.

\subsection{Communication Event}

The recitation of tahlil begins when all the participants (villagers) have come and positioned themselves in the space provided. They sit together and read tahlil led by local religious leaders. The recitation of the tahlil begins in the appropriate order. After the recitation of the tahlil is finished, the pengantin sunat, who has been made up and wearing a special costume, accompanied by her parents, is led to the podium in the shape of a ship to carry out the khataman procession. The procession of khataman is a procession in which the pengantin sunat recites Juz 'Amma (the 30th Juz in the Qur'an) by rote. After the recitation of the tahlil and khataman is finished, the religious leader who leads the reading recites a prayer which indicates that the procession of tahlilan and khataman has been completed. After the procession of tahlilan and khataman, the guests or participants were given berkat containing rice and side dishes and snacks that were placed in the cething and wrapped neatly in plastic. After the procession of tahlilan and khataman is finished, the pengantin sunat is released by her parents with a prayer by being given "sawanan" uba rampe, a finely ground traditional medicine. This finely ground sawan is affixed to part of the child's body. The pengantin sunat riding decorated horses were paraded around the 
village with villagers, relatives, and groups of barongan troops (singo barong and eblek) to every alley or road in the village. During this procession, the group of the pengantin sunat will stop at several houses, such as the house of the village head, the house of the village elders, and the houses of the siblings of the pengantin sunat, to ask for prayers. Usually, the house visited by the pengantin sunat has provided gifts in the form of goods and money to be given to the pengantin sunat. When all the village streets have been passed, the group of pengantin sunat will return home. After the procession is complete, the procession is continued by a singo barong performance (Kibar Barongan) in the courtyard of the pengantin sunat house, which aims to provide entertainment to the local community. A singo barong group consists of several people who have their respective duties, such as playing a traditional musical instrument, being eblek, being a singo barong, as pawang, and as dalang. During the barongan performance, the puppeteer sang several traditional songs accompanied by traditional musical instruments. This ritual has three main communication events based on the details procession above, namely the communication event when a procession of tahlilan and khatamanan, the communication event during arak-arakan, and communication events when the performance of barongan. Therefore, the researchers focused the analysis on tahlilan and barongan performance.

\subsection{Communication Act}

There are acts of verbal communication and nonverbal communication in the selametan khitanan tradition in Demak and this study focus on the analysis of verbal communication in khitan prayer and two traditional songs that accompanied barongan performance because all of them appear in the main communication events of the selametan khitanan tradition in Demak, namely the procession of tahlilan when all of the participants (villagers) have come and positioned themselves in the space provided, then they sit together and read tahlil led by local religious leaders while traditional songs are sung kibar barongan after arak-arakan procession completed.

\subsubsection{Acts of verbal communication in khitan prayers}

After a series of processions of tahlil recitation carried out by the participants led by a religious leader, the recitation of the tahlil prayer is presented. Reading tahlil itself generally aims to say prayers to Allah SWT through tawasul or intermediaries of people who are pleased by Allah SWT in the hope that their prayers can be granted. The researchers have a hypothesis that the recitation of tahlil and prayer tahlil is recited with the same reading by the participants in certain traditional events, especially in Javanese society. Therefore, the researchers only focused on the recitation of the khitan prayer, which is read in the recitation of the tahlil prayer. The khitan prayer recitation is read-only when there is a tradition of khitanan or selametan. The following is the recitation of the prayer of khitan, which is read during the recitation of the prayer tahlil.

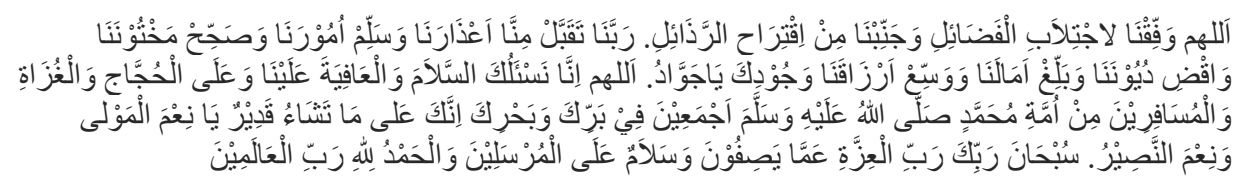

Allahumma waffiqnaa lijtilaabil fadhaail, wajannibnaa min iqtiraahir radzaail. Rabbanaa taqabbal minna a'dzaaranaa wa sallim umuuranaa wa shahhih makhtuunanaa waqdhi duyuunanaa wa balligh aamaalanaa wawassi' arzaaqanaa wajuudika yaa jawwaad. Allahumma innaa nas alukas salaama wal'aafiyata 'alainaa wa 'alal hujjaaji 
walghuzaati walmusaafiriina min ummatin muhammadin shalallahu alaihi wa sallama ajma'iin, fii barrika wa bahrika innaka 'alaa maa tasyaaa u qadiir, yaa ni'mal maulaa wa ni'mannashiir

'O Allah, give us a helping hand to obtain Your virtue, and keep us from humiliating deeds. O Allah, please accept our circumcision, save our affairs, heal our pain due to this circumcision, pay our debts, realize our ideals, and expand our sustenance, $\mathrm{O}$ Who Giving. O Allah, may You provide salvation to us, those who perform the pilgrimage, those who fight in Your way, as well as to the travellers, namely the people of Rasulullah Muhammad Sallallahu Alaihi Wasalam, both on land and at sea. Surely You have power over what You want, O best master and best helper. Glory be to Allah, the Lord who has holiness and all the lower qualities that they (unbelievers) embed. And welfare for the messengers of Allah. All praise belongs to Allah, Lord of the Universe.'

From the recitation of the circumcision prayer chanted during the tradition of selametan khitanan in Demak, there is a communication between the servant to his Lord (Allah SWT). This prayer is specified for children who are circumcised in order to avoid various kinds of dangers. In Islam, boys who have grown up are obliged to be circumcised. Therefore this prayer also requests that the circumcision of the child be accepted by Allah SWT. The hopes expressed are intended so that children can get through their adolescence physically, spiritually, and mentally because, during the growth period, there were a lot of explorations carried out by teenage boys. During their exploration, they prayed that they would always remain protected and protected. Blessing from Allah SWT and avoidance of the bad things that can happen to the circumcised child.

In addition, the request for the child to recover quickly from the pain because after being circumcised is also said in the chanting of a circumcision prayer. There are also requests regarding the mercy of sustenance and the ability to pay off debts for someone who is in debt. In the prayer, there is also a request to be given salvation to the chanter of the prayer, people who go on the pilgrimage, people who are struggling in the way of Allah, travellers, and all the people of the prophet Muhammad SAW which are on the mainland and those who are there at sea. Because of all those who have been asked for their safety, they are in a position that most needs to be given protection such as, for example, people who are going to conduct Hajj where they are carrying out the fifth pillar of Islam which is located in the country of Saudi Arabia, meaning that to carry out the Hajj requires a process that does not help and centred in one place where Muslims all over the world perform the Hajj.

\subsubsection{Acts of verbal communication in traditional song in barongan performance}

The traditional song is sung during Kibar Barongan or the last procession in the series of circumcision during selametan khitanan in Demak. This song is sung to accompany the performance of the eblek (people who ride on braid ropes) when Kibar Barongan continues to dance. Among the traditional songs sung during barongan kibar barongan are traditional songs entitled Lir-ilir and Sluku-sluku Bathok. From a historical perspective, the two songs are composed by Sunan Kalijaga, namely, one of the wali of the walisongo who teaches Islam in the northern coastal area of Demak. The two songs were used by Sunan Kalijaga as a medium of preaching. The lyrics of the song are as follows.

Lir ilir traditional song lyric
(1) Lir ilir lir ilir
Wake up wake up
'Get up, wake up !'
(2) Tandure
wis

sumilir 
SUBJ-the plant already blossom

'The plants have blossomed'

(3) Tak ijo royo-royo

ADV-so green

'So green'

(4) taksenggo temanten anyar

ADJ-like bride ADJ-new

'Like a new bride'

(5) Cah angon cah angon

NAME-shepherd boy NAME-shepherd boy

'Shepherd boy'

(6) penekno blimbing kuwi

climb - O OBJ-start fruit DET

'Climb the star fruit tree'

(7) Lunyu lunyu penekno

Slippery climb-CAUS

'Even if it's slippery keep climbing'

(8) Kanggo basuh dodot iro

PREP wash OBJ-clothes POS-you

'To wash your clothes'

(9) Dodot iro dodot iro

Clothes POS-you clothes POS-you

'Your clothes, your clothes'

(10) kumintir bedhah ing pinggir

to apart PREP side

'Ripped apart on the side'

(11)Dondomono jlumatono

Sew-NO fix-NO

'Sew it up, fix it'

(12) kanggo sebo mengko sore

Use face DET afternoon

'To face it later in the afternoon'

(13)Mumpung padhang rembulane

While light moon-E

'While the moon is shining brightly'

(14)mumpung jembar kalangane

While large free time

'As long as there is a lot of free time'

(15) Yo surako surak iyo

Yes cheers cheers yes

'Cheers with cheers 'Yes!',

In the traditional song Lir-ilir in the first fragment there is Lir ilir, lir ilir which literally means 'Wake up, wake up' which has a symbolic meaning where mankind must wake up and should not be lazy in worshiping God. Because if you look at the historical side, this song was originally used by one of the Walisongo, Sunan Kalijaga, to preach the spread of Islam through art and the song Lir-ilir was created. The fragment of Tandure wis sumilir, which means the plant has bloomed, the selection of the lexicon of 'plant' or tandure implies that one's faith is like a plant that needs to be preserved and cared for with sufficient worship intake so that it can bloom and bloom green like the newlyweds in the lyrics of senggo temanten anyar. What is meant by cah angon, which means 'a shepherd boy' is a human 
being who has been given a heart that must be shepherded or guided to hold his lust with reference to the five pillars of faith which are likened to 'star fruit' which has the shape of five angles in the lyrics of penekno belimbing kui. To achieve perfection in living the five pillars of Islam. The lyrics of lunyu lunyu penekno have the meaning that humans are expected to try hard like someone climbing a slippery tree. The purpose of carrying out the five pillars of Islam is implied in the lyrics of kanggo basuh dodot iro, which means to wash your clothes, which means to purify yourself with devotion because as a human you are sure not to be spared from doing many mistakes and sins that are manifested in the lyrics of dodot iro kuminthih bedhah ing pinggir, dondomonono jlumotono kanggo sebo mengko sore which means your clothes are torn on the side and can be sewn to face later in the afternoon which means that you can fix yourself and improve yourself in piousness to face death with sufficient worship provisions. To raise enough worship, hopefully do it while still healthy and have a lot of free time, as in the lyrics of padhang rembulane, while jembar kalangane are. And when someone reminds you to worship, it is expected that you will answer 'yes' like on the last fragment yo surako surak iyo.

In the traditional songs of the Sluku-sluku Bathok, the first fragment contains the lyrics of the Sluku-sluku Bathok which means 'swing-swing head' which means that life in a world is not good if only spent on work, there needs to be a balance between work and rest. The word bathok which means 'head' needs a short break to be used again in thinking about doing work. The second fragment in the lyrics of sirama menyang solo if it is cut off can become sirama which literally becomes 'bath', here what is meant by bathing is purification. In Islam bathing is one way to purify the body. Menyang means 'go' and Solo in the fragment means 'salat/pray'. So the second fragment has the meaning of ordering humans to purify themselves both thoughts and actions before performing worship. The next lyrics is oleh-olehe payung mutho, which literally means 'souvenir umbrella moutho'. The mutho umbrella is a thick and wide umbrella, so the meaning of this lyrics is that if you have worshiped Allah SWT, you will get a broad protection which is manifested from the word 'umbrella mutho'. The next fragment is mak jenthit lolo loba which literally means "suddenly moving". The meaning of the fragment is the arrival of a sudden death. Death is a certainty that comes no one knows and often comes suddenly, death cannot be postponed or enhanced by its arrival. The lyrics of wong mati ora obah which means 'a person who has died does not move' have food if death has come there is no more opportunity to worship because it is too late. The fragment yen obah medeni bocah has the literal meaning of "moving to scare a child". The meaning of this fragment is that many souls who have died regret that during their lives they have not had the opportunity to do good things and want to live again but cannot because if the dead comes back to life and moves, it will be scary. The last fragment of the yen urep golek duit from this traditional song has the meaning literally "if life earns money" meaning when life is the best time to worship before dying, because when you die, the time to worship is over.

Sluku-sluku Bathok traditional song lyric

(1) Sluku-sluku bathok

Swinging head

'The swinging head'

(2) Bathok'e ela-elo

head-E shook

'The head shook'

(3) $\mathrm{Si}$ romo menyang solo

DET father go PLACE

The father went to Solo

(4) Oleh-olehe payung mutho

The souvenir-E umberella NAME 
The souvenir was Mutha umberella

(5) Makjenthit lolo loba

Suddenly move

Suddenly moved

(6) Wong mati ora obah

The dead MOD-not move

The dead don't move

(7) Yen obah medeni

If move ACT-scare

If It moves to scare the children

$\begin{array}{lllll}\text { (8) Yen } & \text { urep } & \text { golek } & \text { yo } & \text { duit } \\ \text { If } & \text { live } & \text { look for } & \text { LIT } & \text { OBJ-money }\end{array}$

Then they will make money

bocah

OBJ-childre

\subsubsection{Harmonization among culture, religion, and nature in khitan prayer and traditional songs}

By analyzing the intertextual meaning and analyzing the communicative events of the tradition of selametan khitanan in Demak, the researchers present the harmonization between culture, religion and nature contained in this tradition. The researchers focused on analysing do'a khitan and two traditional songs, namely Lir-ilir and Sluku-sluku Bathok. In the khitan prayer, it is very clear that the religiosity came from the use of Arabic in reciting the khitan prayer, which Arabic is very closely related to Islam. In the Islamic religion, the main guidelines are Al-Qur'an and Al-hadith, which use Arabic and the reading of tahlil, tahlil prayer, and the khitan prayer that is in the procession of selametan khitanan in Demak. The religious element is also very thick in the relationship between khitan prayer, traditional songs of Sluku-sluku Bathok, and lir-lir with the meaning that exists in all three of which shows a similarity, explaining the relationship and communication between humans and Allah SWT as previously explained.

Cultural elements can also be seen in the series of selametan khitanan pngantin sunat as evidenced by the distribution of berkat as a sign of gratitude for parents who have grown-up sons, the tradition of distributing food called berkat is a tradition of ancient Javanese people that has been preserved until now. Before the emergence of Islam, the ancient Javanese gave this berkat in offerings to their ancestors in expressing their gratitude. In addition, barongan art is also displayed to entertain the local community. The function of the barongan performance has shifted from a sacred ritual to entertainment for the community over time. In barongan performances, there are many cultural elements, including in barongan performances, there are traditional songs of Sluku-sluku Bathok and Lir-ilir in specific sessions to be sung. In Javanese culture, Sluku-sluku Bathok songs are commonly used to accompany a Javanese children's game called selojor. From the Selorjor game, there is a solidarity value. When this game is played, the children will sing simultaneously with a compact movement. In the shell songs as well. Until now, this game is still played by children, but it is rarely found.

It has natural elements from khitan prayer, traditional songs Sluku-sluku Bathok, and traditional songs lir-lir that can be seen from the use of certain lexicons. In the prayer of circumcision, there is a phrase that means 'land and sea', indicating that the earth currently inhabited by humans consists of land and sea according to the knowledge humans have, and it has been proven concretely. Then the natural elements in the song lir ilir appear in lexicon tandur 'plants' and belimbing 'star fruit'. The tandur lexicon shows the Demak region, which has extensive rice fields and well-known rice yields. Judging from the superior agricultural sector in Demak, it can reach the highest level that the people there work as 
farmers. Besides being famous for its harvest, star fruit is also an icon of fruit from the city of Demak, star fruit produced from Demak is known to have a delicious taste and large fruit size. Besides star fruit, there is also water guava, which is famous from Demak because of its sweet taste and large size. From the good yields and fruit yields in Demak, it can be shown that Demak has a suitable land for growing fruit and rice.

\section{Conclusion}

Through the tradition of the bride and groom of circumcision in Demak, there are three sub-events, namely; 1) Procession of tahlilan and khataman, 2) procession of arak-arakan, and 3) Performance of Barongan. Each sub-event has different participants, goals and communication patterns. In the tahlilan procession, the participants are local villagers, men and women who wear closed and neat clothes, which are placed in the house of the pengantin sunat to ask Allah SWT for all goodness. In the tahlilan procession with the same participants, there is a khataman procession carried out by the pengantin sunat using specific costumes on a special podium. The second sub-event is a procession of arak-arakan. More participants in this sub-event are no longer set in the house of pengantin sunat but are set along the village road and several houses of relatives and village chiefs. In the last sub-event in the yard of the pengantin sunat, the performance of barongan is a sign that the procession has ended. There is the harmonization between religion, culture, and nature from a series of processions carried out. It can be seen from several special series and particular lexicons that appear from several texts in tahlil prayer that are read at the end of the procession of tahlilan and the songs sung during the procession of kibar barongan in selametan khitanan in Demak. In tahlil prayer, it is very clear that the religious element is very concentrated because it is carried out with the background of the Islamic religion, which is a request that there are also several lexicons related to the universe. Likewise, the songs sung during the kibar barongan procession, the songs sung contain meanings that are closely related to nature, culture, and also religion so that it can be seen that there is harmony between religion, culture, and religion in the circumcision procession in Demak.

\section{References}

1. J. Y. Sasaki, H. S. Kim, JPSP, 101, 401-414 (2011)

2. A. A. B. Salmani, S. Arifin, D. Dahlan, JIP, 3, 44-51 (2019)

3. Erwarnto, E. Contessa, JPBS, 13, 139-144 (2020)

4. A. Mulyana, IJHSS, 4, 50-61 (2017)

5. J. P. Williams, Sage Encyclopedia of Qualitative Research Methods (2008)

6. S. Q. Qu, J. Dumay, EGP, 8, 238-264 (2011)

7. M. Q. Patton, ESBS, 3, 1633-1636 (2005)

8. S. Troike, Muriel, The Ethnography of Communication: An Introduction (2003)

9. N. P. S. Widiastuti, I. M. A. A. Gunawan, N. P. D. P. Sari, JPBS, 19, 184-202 (2020)

10. I. Marwan, MZ, 19, 99-117 (2017) 